\title{
Screening of Ber (Zizyphus mauritiana Lamk) Cultivars / Germplasm against Alternaria alternata (Fr.) Keissler Causing Alternaria Leaf Spot
}

\author{
Akash Kumar*, H. K. Singh and Satya Prakash Vishwakarma \\ Department of Plant Pathology, Acharya Narendra Deva University of Agriculture and \\ Technology, Kumarganj, Ayodhya-224 229 (U.P.) India \\ *Corresponding author
}

\begin{tabular}{|c|}
\hline Keywords \\
\hline $\begin{array}{l}\text { Ber, } \\
\text { Zizyphus } \\
\text { mauritiana }\end{array}$ \\
\hline Article Info \\
\hline $\begin{array}{l}\text { Accepted: } \\
\text { 10 September } 2020 \\
\text { Available Online: } \\
10 \text { October } 2020\end{array}$ \\
\hline
\end{tabular}

\section{A B S T R A C T}

Ber (Zizyphus mauritiana Lamk) is one of the important fruit crops of arid and semi arid zones of the world. In India though it is a minor fruit but recently the ber become an important cash crop in some areas and its acreage and production are increased. Due to rapid spread of commercial cultivation, the crop is also affected by different biotic and abiotic factors including pathogens causing many serious diseases. Among the diseases, Alternaria alternata is one of the most important, widespread and easily recognized disease. The disease is characterized by the formation of small, irregular brown spots on upper surface of leaves. Corresponding lower side appears with dark brown to black spot 3 to $6 \mathrm{~mm}$ in diameter with a gray to tan centre and distinct brownish yellow margins. Under humid conditions, black patches comprising plenty of conidia can be seen and which severe as air borne inoculation. As in case of ber plants, under severe conditions many spots coalesce to form big patches and later such leaves defoliated from branches. In varietal screening, forty varieties/germplasm was screened against Alternaria alternata (Fr.) Keissler. It was recorded that none of the variety was found free from disease and only 3 germplasm, Narendra ber Selection-1 (3.50\%) Seo (4.0\%) and Narendra ber Selection-2 (4.60\% area covered with the pathogen) were found resistant and 20 genotypes having disease intensity 5.01 to $20 \%$ area covered with the pathogen were moderately susceptible, 13 genotypes having disease intensity to 20.01 to $50 \%$ area covered with the pathogen were susceptible and 4 genotypes namely genotypes having disease intensity > $50 \%$ area covered with the pathogen were found highly susceptible.

\section{Introduction}

Indian jujube or ber (Zizyphus mauritiana Lamk.) is one of the most common fruit; indigenous to an area joined from India to China belongs to family Rhamnaceae. It is also known as Chinese date or Chinese fig or plum and commonly considered as poor man's fruit. It is popularly called the king of arid zone fruit (Yamadagni, 1985; Shoba and Bharathi, 2007; Mishra et al., 2013). This fruit probably originated in India. It is reported to be grown in other countries like Iran, Syria, Australia, USA, France, and certain part of Italy, Spain, Africa, etc. Precisely, it is seen to grow under tropical and 
sub-tropical as well as Mediterranean region of the world. In view of the gaining popularity, area under this fruit is being increased gradually day by day. Ber orchards are generally found in Varanasi, Mirzapur, Sonbhadra, Jaunpur, Aligarh, Ayodhya, Agra and Raebareli districts of Uttar Pradesh (Singh et al., 1973)

The ber fruit has high sugar content (sucrose, glucose, fructose and starch). It is therefore high in carbohydrates, which provide energy. The levels of sugars vary according to cultivar. The fruits also contain protein with many essential amino acids (asparginine, arginine, glutamic acid, aspartic acid, glycine, serine and threonine). General nutritive composition of ber fruits is reported by Morton, 1987; Pareek and Dhaka, 2008 and Pareek et al., 2009.

The ber is a heat and drought tolerant fruit crop with high productivity under arid and semi-arid condition (Pareek 1983). Several species of Zizyphus can endure extreme stress caused by drought, salinity and in some cases water logging. The ber cultivar Gola is one of the most important cultivar and requires less degree days of maturity (Singh et al., 1983). Production of ber is affected by a large number of biotic and abiotic stresses (Gupta and Madaan, 1977).

Among the biotic diseases, Alternaria alternata is one of the most important, widespread and easily recognized disease. In
Uttar Pradesh, Alternaria leaf spot of ber disease was minor but due to climatic changes, it was recorded moderate to severe form among the commercial cultivars during recent years. The present investigation aims ultimately to find out to management strategy for leaf spot of ber disease that suits agroclimatic conditions of the country. In the absence of stable management strategy, use of resistant varieties, against Alternaria leaf spot of ber is the only recommendation for the management of leaf spot of ber.

\section{Materials and Methods}

Twenty five years old of 40 cultivars/ germplasm/variety grown at Main Experimental Station, Horticulture, Acharya Narendra Deva University of Agriculture and Technology, Kumarganj ( $26^{\circ} 47^{\prime}$ N, $82^{\circ} 12^{\prime}$ E, 113 msl), Ayodhya (U.P.), India. The symptoms were recorded from initial stage to final stage. Per cent disease severity was also recorded at initial stage to peak of disease under Randomized Block Design with three replications (one tree per replication) 50 leaves of a tree were picked up randomly when the disease severity was high and per cent disease intensity was calculated as per 05 disease rating scale for assessing host reaction against Alternaria leaf spot of ber is as follows scale given by McKinney (1923). The symptoms were recorded from initial stage to final stage.

\begin{tabular}{|c|l|}
\hline Rating scale & Average per cent disease intensity \\
\hline $\mathbf{0}$ & $0 \%$ area covered with the pathogen \\
\hline $\mathbf{1}$ & $0.1-5 \%$ area covered with the pathogen \\
\hline $\mathbf{2}$ & $5.1-20 \%$ area covered with the pathogen \\
\hline $\mathbf{3}$ & $20.1-50 \%$ area covered with the pathogen \\
\hline $\mathbf{4}$ & $50.1-75 \%$ area covered with the pathogen \\
\hline $\mathbf{5}$ & $75.1-100 \%$ area covered with the pathogen \\
\hline
\end{tabular}


Disease severity of leaf spot of ber on varieties/genotypes, was recorded using 0-5 point scale as mentioned above and genotypes were classified based on their categorization on the basis of per cent disease intensity are as follows:

\begin{tabular}{|c|l|l|}
\hline Rating scale & \multicolumn{1}{|c|}{ Description } & \multicolumn{1}{c|}{ Host reaction } \\
\hline $\mathbf{0}$ & 0 No infection & Immune \\
\hline $\mathbf{1}$ & 0.1-5 area covered with the pathogen & Resistant \\
\hline $\mathbf{2}$ & 5.1-20 area covered with the pathogen & $\begin{array}{l}\text { Moderately } \\
\text { susceptible }\end{array}$ \\
\hline $\mathbf{3}$ & 20.1-50 area covered with the pathogen & Susceptible \\
\hline $\mathbf{4}$ & $\mathbf{> 5 0 . 1 \%}$ area covered with the pathogen & Highly susceptible \\
\hline
\end{tabular}

The per cent disease intensity (PDI) was calculated by by employing formula mentioned below:

$$
\text { PDI }=\frac{\text { Sum of all numerical ratings }}{\text { Total number of leaves examined } \mathrm{x} \text { Highest rating }} \times 100
$$

\section{Results and Discussion}

\section{Symptomatology}

The disease is characterized by the formation of small, irregular brown spots on upper surface of leaves. Corresponding lower side appears with dark brown to black spot 3 to 6 $\mathrm{mm}$ in diameter with a gray to tan center and distinct brownish yellow margins. Under humid conditions, black patches comprising plenty of conidia can be seen and which severe as air borne inoculation. As in case of ber plants, under severe conditions many spots coalesce to form big patches and later such leaves defoliated from branches (Fig. 1A to D). Similar symptoms were also recorded by Pareek (1983); Mehmood et al., (2018), Kaur et al., (2020) and reported Alternaria leaf spot of ber symptoms.

\section{Varietal screening}

Forty genotypes/varieties were selected for screening against leaf spot disease under natural field conditions. It was recorded that, none of the variety/genotypes was found free from disease the observation on leaf spot incidence was recorded on the basis of 0-5 disease rating scale. Out of forty genotypes/varieties screened under natural conditions.

Minimum per cent disease intensity was recorded in 3 genotypes namely Narendra Ber sel.-1 (3.50) followed by Seo (4.00), Narendra Ber Sel. -2 (4.60) proved resistant; 20 genotypes namely Goli (6.00), Narendra Ber Sel.- 3 (7.00), Banarasi Karaka (9.00), Tikdi (9.00), Seedless (9.00), Mirchia (10.00), Kala Gola (10.00), Kaithali (11.00), Darakhi No.1 (11.00), Backwadi (12.00), Godhan (14.00), Kali (15.00), Safeda Rohtak (15.00), Katha Rajasthani (17.00), Z-G-3 (18.00), Pathan (19.00), Akhrot (19.00), Narendra Ber Sel. 4 (19.00), Villaiti (20.00) and Banarasi Peondi (20.00) were found moderately susceptible.

Narenra Ber Sel. 5 (21.00), Sunaur-5 (21.00), Narma (26.00), Gola (29.00), Kakrola Gola (30.00), Peondi (33.00), Mudia Murhara (33.00), Jalandhar (35.00), Chhuhara (35.00), Safeda Seremon (40.00), Illaichi (45.00), Katha (45.00) and Umran (45.00) were found susceptible and 4 genotypes namely Reshmi (52.00), Sanaur-3 (55.00), Sindura Narnaul (60.00), Ponda (62.00) were found highly susceptible (Table 1). 
Table.1 Screening of ber cultivars against Alternaria alternata causing Alternaria leaf spot of ber under natural conditions

\begin{tabular}{|c|c|c|c|}
\hline S. No. & Germplasm/Varieties & Per cent Disease Intensity (PDI) ${ }^{*}$ & Host reaction \\
\hline 1. & Kali & $15.00(22.78)$ & MS \\
\hline 2. & Kakrola Gola & $30.00(33.19)$ & $\mathrm{S}$ \\
\hline 3. & Mirchia & $10.00(18.43)$ & MS \\
\hline 4. & Reshmi & $52.00(46.15)$ & HS \\
\hline 5. & Katha & $45.00(42.13)$ & $\mathrm{S}$ \\
\hline 6. & Safeda Rohtak & $15.00(22.78)$ & MS \\
\hline 7. & Umran & $45.00(42.13)$ & $\mathrm{S}$ \\
\hline 8. & Banarasi Karaka & $9.00(17.43)$ & MS \\
\hline 9. & Villaiti & $20.00(26.56)$ & MS \\
\hline 10. & Tikdi & $9.00(17.45)$ & MS \\
\hline 11. & Kala Gola & $10.00(18.43)$ & MS \\
\hline 12. & Pathan & $19.00(25.84)$ & MS \\
\hline 13. & Ponda & $62.00(51.94)$ & HS \\
\hline 14. & Jaladhar & $35.00(36.23)$ & $\mathrm{S}$ \\
\hline 15. & Godhan & $14.00(21.95)$ & MS \\
\hline 16. & Illaichi & $45.00(42.12)$ & $\mathrm{S}$ \\
\hline 17. & Seo & $4.00(11.53)$ & $\mathrm{R}$ \\
\hline 18. & Banarasi Peondi & $20.00(26.56)$ & MS \\
\hline 19. & Backwadi & $12.00(20.23)$ & MS \\
\hline 20. & Katha Rajsthani & $17.00(24.35)$ & MS \\
\hline 21. & Z-G-3 & $18.00(25.10)$ & MS \\
\hline 22. & Narma & $26.00(30.65)$ & $\mathrm{S}$ \\
\hline 23. & Sanaur-3 & $55.00(47.87)$ & HS \\
\hline 24. & Gola & $29.00(32.54)$ & $\mathrm{S}$ \\
\hline 25. & Mudia Murhara & $33.00(35.05)$ & $\mathrm{S}$ \\
\hline 26. & Safeda Seremon & $40.00(39.23)$ & $\mathrm{S}$ \\
\hline 27. & Kaithali & $11.00(19.37)$ & MS \\
\hline 28. & Sindura Narnaul & $60.00(50.77)$ & HS \\
\hline 29. & Sunaur-5 & $21.00(27.27)$ & $\mathrm{S}$ \\
\hline 30. & Chhuhara & $35.00(36.26)$ & $\mathrm{S}$ \\
\hline 31. & Akhrot & $19.00(25.82)$ & MS \\
\hline 32. & Peondi & $33.00(35.04)$ & $\mathrm{S}$ \\
\hline 33. & Seedless & $9.00(17.45)$ & MS \\
\hline 34. & Goli & $6.00(14.18)$ & MS \\
\hline 35. & Darakhi No. 1 & $11.00(19.37)$ & MS \\
\hline 36. & Narendra Ber Selection -1 & $3.50(10.76)$ & $\mathrm{R}$ \\
\hline 37. & Narendra Ber Selection- 2 & $4.60(12.38)$ & $\mathrm{R}$ \\
\hline 38. & Narendra Ber Selection -3 & $7.00(15.34)$ & MS \\
\hline 39. & Narendra Ber Selection- 4 & $19.00(25.84)$ & MS \\
\hline \multirow[t]{3}{*}{40.} & Narendra Ber Selection- 5 & $21.00(27.23)$ & $\mathrm{S}$ \\
\hline & SEm \pm & 0.82 & -- \\
\hline & $\mathrm{CD}(\mathrm{P}=0.05 \%)$ & 2.31 & -- \\
\hline
\end{tabular}

Average of three replications

Figures given in parenthesis are angular transformed values.

$\mathrm{R}=$ Resistant, $\mathrm{MS}=$ moderately susceptible, $\mathrm{S}=$ Susceptible, $\mathrm{HS}$ =highly susceptible 
Fig.1 A-D: The disease symptoms at different stages of disease development on leaves

A
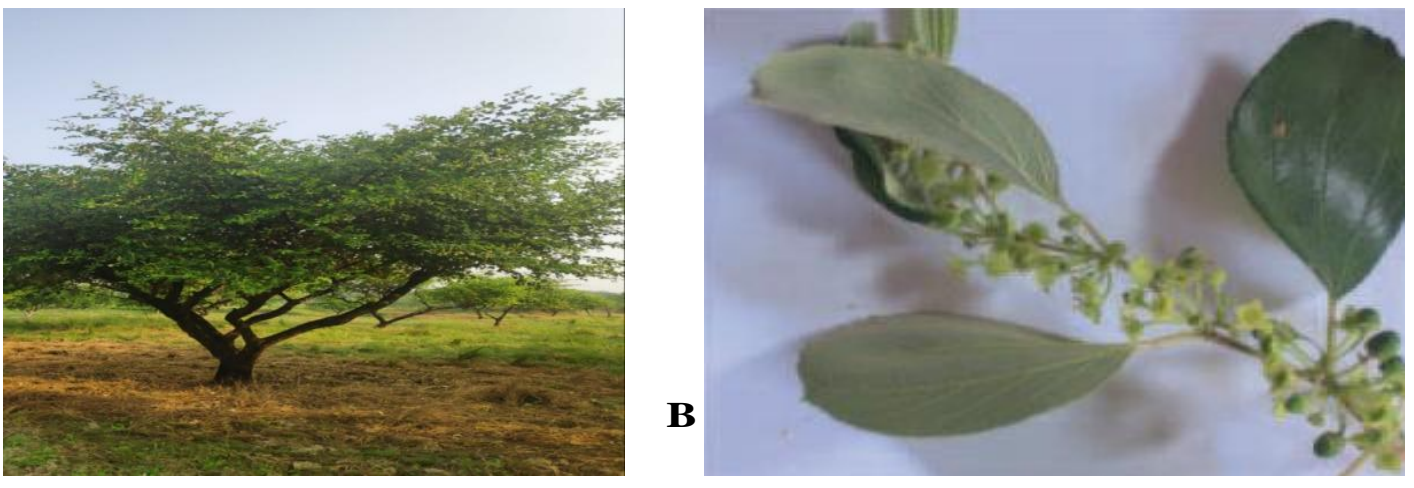

Experimental field view of ber plant and healthy Leaves
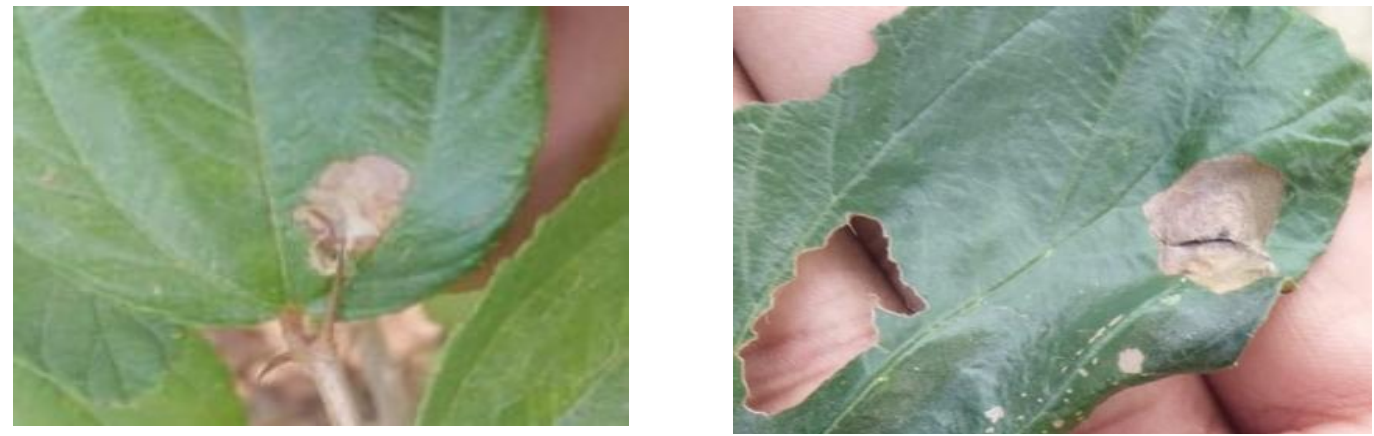

A
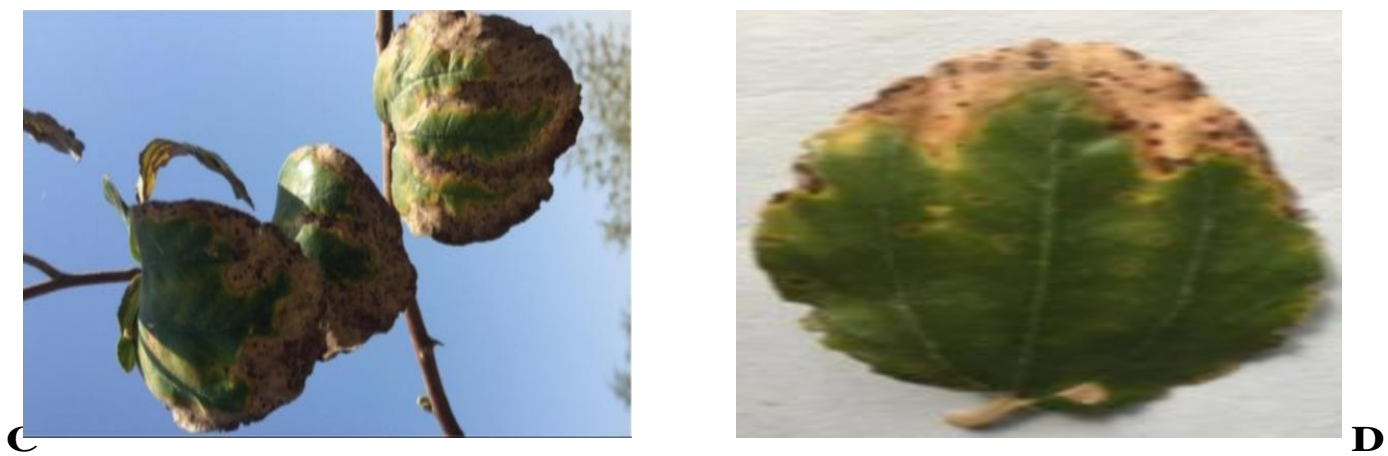

\section{Symptoms of Alternaria leaf spot}

Kaur et al., (2020) tested 21 cultivated varieties, Sanuar-2 showed maximum (20.7\%) while Kaithali showed minimum (4.7\%) disease incidence. Out of twenty one ber cultivars, Sanuar-2 was susceptible whereas Thornless, Sanuar-4, Pathani, Safeda, Selected Safeda, Seo and Nalagarh were resistant to the disease. Chaudhary et al., (2017) also screened 21 ber cultivars against Oidium erysiphoides f. sp. zizphi causing powdery mildew and found Darakhi-2 and Nazuk cultivars were categorized are resistant as these showed 2.60 and 4.67 per cent disease intensity respectively. 


\section{References}

Chaudhary, M., Ghasolia, R.P., Lakharan, L. and Bajaya, T. (2017). Screening of ber cultivars/germplasm against Oidium erysiphoides f. spp. Ziziphi, causing powdery mildew. J. Pharmacognosys Phytochem. 6(4): 1336-1367.

Gupta PC and Madaan RL (1977a) Diseases of fruits from Haryana. A new leaf spot disease of Ziziphus mauritiana Lamk. Current Science, 46: 237-238.

Kaur, M., Thind S. K. and Arora A. (2020). Prevalence of ber black fruit spot (Alternaria alternata) and its management. Indian Phytopath. 73:245-251.

https://doi.org/10.1007/s42360-02000229-8.

McKinney H.H. (1923). A new system of grading plant diseases. Agric. Res.; 26: 95-98.

Mehmood, N., Abbas, M.F., Rafique, K., Sattar, A., Ghuffar, S., Qamar, M.I. and Shahid, M. (2018). First Report of Ber (Zizyphus mauritiana) Leaf Spot Caused by Alternaria alternata in Pakistan. Plant Disease 102(12) https://doi.org/10.1094/PDIS-12-172017-PDN.

Misra, D.K., Saha J., Devidas, P.V. and Bauri, F.K. (2013). Diseases of ber (Zizyphus jujube) in Eastern India. The Journal of Plant Protection Sciences, 5(1): 65-69, June, 2013
Morton, J. (1987). Indian Jujube. http://www.hort. purdue.edu/newcrop/ morton/ Indian jujube. html (assessed on 11.07.2020).

Pareek, O.P. (1983). The Ber : Indian Council of Agriculture Research, New Delhi.

Pareek, S. and Dhaka, R. S. (2008). Association analysis for quality attributes in ber. Ind. J. Arid Hort. 3: 77-80.

Pareek, S., Kitinoja, L., Kaushik, R.A. and Paliwal, R. (2009). Postharvest physiology and storage of ber. Stew. Posthar. Rev. 5(5):1-10.

Shoba, D and Bharati, P. (2007). Value addition to ber (Zizyiphus mauritiana Lamk.) through preparation of pickle. Karnataka J. Agril. Sci., 20 (2): 353355.

Singh, K.K., Chadha, K.L., Gupta, M.R. (1973). Ber cultivation in Punjab. Punjab Agricultural University, Plant Disease Research Ludhiana, 48(1): 6569.

Singh, R.R., Jain, R.K., Chauhan, K.S. (1983). Flowering and fruiting behaviour of ber (Ziziphus mauritiana Lamk.) under Gurgaon conditions. Haryana Agricultural University Journal of Research., 13(1): 112-114.

Yamadagni, R. (1985). Ber in: Fruits of India, Tropical and subtropical, Naya Prakashan. Calcutta, India.

\section{How to cite this article:}

Akash Kumar, H. K. Singh and Satya Prakash Vishwakarma. 2020. Screening of Ber (Zizyphus mauritiana Lamk) Cultivars / Germplasm against Alternaria alternata (Fr.) Keissler Causing Alternaria Leaf Spot. Int.J.Curr.Microbiol.App.Sci. 9(10): 973-978.

doi: https://doi.org/10.20546/ijcmas.2020.910.116 